PACS 64. 60. A+82. 70. R

УДК 530. 182, 510. 42

\title{
SENSING AIR POLLUTION FIELD STRUCTURE IN THE INDUSTRIAL CITY'S ATMOSPHERE BY IMAGE RECOGNITION METHOD: NEURAL NETWORKS MODELLING
}

\author{
A. V. Glushkov, Yu. Ya. Bunyakova, G. P. Prepelitsa and T. V. Solonko \\ Institute of Applied mathematics OSEU, P. O. Box 108, Odessa-9, 65009, Ukraine
}

\begin{abstract}
SENSING AIR POLLUTION FIELD STRUCTURE IN THE INDUSTRIAL CITY'S ATMOSPHERE BY IMAGE RECOGNITION METHOD: NEURAL NETWORKS MODELLING
\end{abstract}

A. V. Glushkov, Yu. Ya. Bunyakova, G. P. Prepelitsa and T. V. Solonko

A new approach, based on the image recognition method and neural networks modelling scheme, is at first proposed for sensing temporal and spatial structure of the air pollution fields in the industrial city's atmosphere. As example it has been carried out an analysis of the Odessa atmosphere aerosol component data.

Key words: sensing, city's air pollution, image recognition, neural networks

\section{Анотація}

\section{ДЕТЕКТУВАННЯ СТРУКТУРИ ПОЛЯ ЗАБРУДНЕННЯ АТМОСФЕРИ ПРОМИСЛОВОГО МІСТА НА ОСНОВІ МЕТОДУ РОЗПІЗНАВАННЯ ОБРАЗІВ: НЕЙРОМЕРЕЖЕВЕ МОДЕЛЮВАННЯ}

О. В. Глуиков, Ю. Я. Бунякова, Г. П. Препелица, Т. В. Солонко

Запропоновано новий підхід до детектування просторово-часової структури полів забруднення повітря в атмосфері промислового міста, який базується на методі розпізнавання образів та нейромережевому моделюванні. Схему протестовано на даних по аерозольному пилу в атмосфері м. Одесси.

Ключові слова: детектування, забруднення повітря, промислове місто, розпізнавання образів, нейромережеве моделювання.

\section{Аннотация \\ ДЕТЕКТИРОВАНИЕ СТРУКТУРЫ ПОЛЯ ЗАГРЯЗНЕНИЯ АТМОСФЕРЫ ПРОМЫШЛЕННОГО ГОРОДА НА ОСНОВЕ МЕТОДА РАСПОЗНАВАНИЯ ОБРАЗОВ: НЕЙРОСЕТЕВОЕ МОДЕЛИРОВАНИЕ}

\section{А. В. Глуиков, Ю. Я. Бунякова, Г. П. Препелица, Т. В. Солонко}

Предложен новый подход к детектированию пространственно-временной структуры полей загрязнения воздуха в атмосфере промышленного города, базирующийся на методе распознавания образов и нейросетевом моделировании. Схема протестирована на данных по аэрозольным взвесям в атмосфере г. Одессы.

Ключевые слова: детектирование, загрязнение воздуха, промышленный город, распознавание образов, нейросетевое моделирование 


\section{Introduction}

One of the actual problems of modern atmosphere and environmental physics is carrying out new, effective schemes for sensing air pollution field structure in atmosphere in general and atmosphere of industrial cities in particular (c. f. [1-18]). A great number of different experimental methods are used in studying the atmosphere pollution. Besides standard physical-chemical analysis, in last years a great interest attracts using laser emission analysis schemes. They are based on using different linear and non-linear optical phenomena. In particular, an effect of the low threshold laser clamp on the solid ingredients of the disperse medium [1,2]. This effect is technically realized in real atmosphere on the distances of hundred meters from emitter. Generating the optical emission spectra, electric and magnetic pulses and also acoustical emission follows the distant laser clamp. Within scheme of the distant spectral chemical analysis laser source must provide evaporation of the aerosol component (soil particles, products of the metallurgical and other productions, organic substances etc.) and exciting intensive emission spectra in the corresponding vapours simultaneously. Here it is arisen a class of tasks, connected with studying the key features of the corresponding aerosol components. In last years it has been shown that the aerosol particles are created in many natural processes (coagulation of smoke particles, clusters in the clouds, etc.) and possessed by the fractal structure (c. f. [2-15]). Papers [15-18] have been devoted to development of new, effective theoretically optimal technological schemes for sensing temporal and spatial structure of the air pollution fields in the industrial city's atmosphere and creation of the corresponding laser emission analysis methodises. In particular, it has been developed a new theoretical, so called correlation dimension method to sensing temporal and spatial structure of the air pollution fields in the industrial city's atmosphere and applied to an analysis of the Odessa atmosphere aerosol component data. On the basis of the correlation dimension approach to empirical data we have discovered the effects of stochasticity and fractal features in the dusty air pollution field structure. A discovery of the fractal properties and chaotic dynamics features in the air pollution field structure for industrial city $[15,18]$ opens new possibilities for developing new effective methodises to make sensing the cited field structure. First of all, these possibilities are provided by availability new methods of analysis and model- ling the complex, non-linear dynamical systems. Speech is about the image recognition method and neural networks modelling schemes $[3,4]$. In this paper a new approach, based on the image recognition method and neural networks modelling scheme, is at first proposed for sensing temporal and spatial structure of the air pollution fields in the industrial city's atmosphere. As example it has been carried out an analysis of the Odessa atmosphere aerosol component data (spatial distribution).

\section{Image recognition method and meural networks modelling scheme}

The model, based on neural network [4], has been worked out to forecast the air pollution fields in the industrial city's atmosphere in space and time. The model has been tested on the measured and compilated data on the dusty concentration (2000-2002 years), obtained and described in ref. [19]. This product provides maps of maximum values of the dusty concentration projection upon the horizontal surface in the range of about $40 \mathrm{~km}^{2}$ with spatial resolution $0,2 \times 0,2 \mathrm{~km}$. The input data applied to the model has consisted of sequences of $\mathrm{N}$ consecutive images with $15 \mathrm{~min}$. time step. The forecast has been calculated for the next 15 minutes.

The neural network $(\mathrm{NN})$ is a feed-forward nonlinear three-layer learning network, consisting of input, hidden and output layers (c. f. [4,5]). In ref. [5] the same neural networks scheme has been used in modelling precipitation intensity fields. Each layer is composed of $n_{k}$ nodes and consecutive layers (k-1 and $\mathrm{k})$ are interconnected by arrays of weights $\left(\mathrm{w}_{\mathrm{i}, \mathrm{j}}{ }^{\mathrm{k}}\right)$. At first the neural network is trained on a large sample of representative data. Training is to optimise weights on the basis of the error between the expected and calculated outputs. It is conducted with back propagation algorithm on $\mathrm{N}+1$-element sequences of radar images. The rainfall values in all $\mathrm{n}_{0}$ pixels of the whole radar maps sequence constitute the input vector $\mathrm{y}_{\mathrm{i}}^{0}$.

Table 1.

Data vectors applied in the model

\begin{tabular}{|c|c|c|c|}
\hline Layers & Denitation & Range & Size \\
\hline $1^{\text {st }}$ input layer & $\mathrm{y}_{\mathrm{i}}{ }^{\mathrm{i}}$ & $\mathrm{i}=1, \ldots, \mathrm{n}_{0}$ & $\mathrm{n}_{0}=\mathrm{n} \times 100$ \\
\hline $2^{\text {nd }}$ hidden layer & $\mathrm{y}_{\mathrm{i}}{ }^{1}$ & $\mathrm{i}=1, \ldots, \mathrm{n}_{1}$ & $\mathrm{n}_{1}=300$ \\
\hline $3^{\text {rd }}$ output layer & $\mathrm{y}_{\mathrm{i}}{ }^{2}$ & $\mathrm{i}=1, \ldots, \mathrm{n}_{2}$ & $\mathrm{n}_{2}=1 \times 100$ \\
\hline Expected output & $\mathrm{y}_{\mathrm{i}}{ }^{3}$ & $\mathrm{i}=1, \ldots, \mathrm{n}_{3}$ & $\mathrm{n}_{3}=1 \times 100$ \\
\hline
\end{tabular}


The vector $y_{i}{ }^{0}$ is transformed into the vector $y_{i}{ }^{1}$ (hidden layer), which in turn is transformed into the output vector $\mathrm{y}_{\mathrm{i}}^{2}$. Both transformations are performed using arrays of weights $w_{i, j}^{k}$ according to the following formula

$$
y_{i}^{k}=f\left\{\sum_{j=1}^{n_{k}-1} w_{i, j}^{k} y_{j}^{k-1}+w_{i, 0}^{k}\right\} \quad \mathrm{i}=1, \ldots, \mathrm{n}_{\mathrm{k}} ; \mathrm{k}=1, \ldots, 2 ;
$$

In the above formula the function $\mathrm{f}$ is so-called transfer function; we use sigmoid function:

$$
F=1 /\left[1+x^{b(D)}\right]
$$

Here $b(D)$ is sigmoid transfer function parameter, which requires optimisation; $\mathrm{D}$ is a fractal dimension (c. f. [18]). In figure 2 a qualitative shape of response function for direct propagation (curve 1) of the patterns chain (massive of values of the air pollution concentration) and for reverse propagation (curve 2) is presented. They are close to function, which is corresponding to derivative of the response function. Such a choice provides an optimal realization of the leaning process for neural network. From mathematical point of view the neural network leaning process is multi-parameter task of the non-linear optimization. The referent process is in choice of optimized values of matrix elements for given topology of links between neurons. A regular output vector is formed on output for introduction of input vector from training pattern chain to neural network (i. e. output vector practically coincides with expected sample vector and further process of leaning is finished). It should be noted that a method of reverse mistake propagation is in fact a generalization of the non-linear squares approach to multi-layers neural network (see detailed description in ref. [4]).

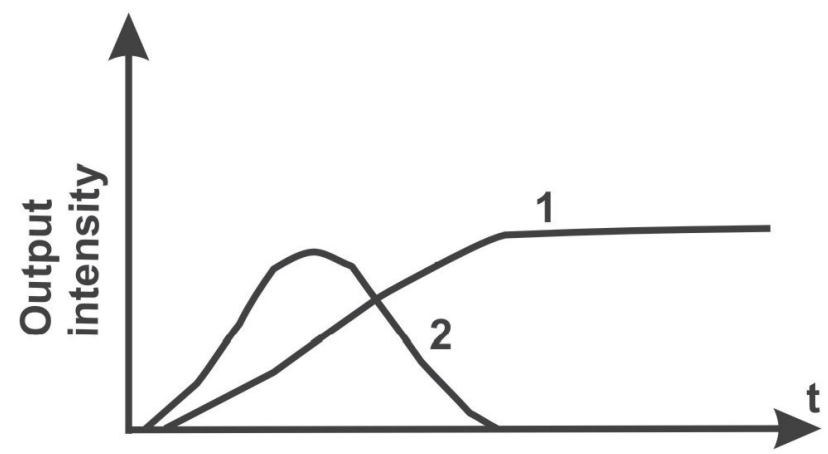

Fig. 1. The response function of neuron in the neural network: 1 - response for direct propagation of the patterns chain (massive of values of the air pollution concentration); 2 - for reverse propagation; I- output intensity of data
The output vector $y_{i}^{2}$ constitutes the result of model process, i. e. now casting of $(\mathrm{N}+1)$ st element in the radar images sequence. It is compared with the expected real values from the time the forecast is prepared for. Thus it is possible to calculate the error: $\mathrm{e}_{\mathrm{i}}^{2}=\mathrm{y}_{\mathrm{i}}^{3}-\mathrm{y}_{\mathrm{i}}^{2}, \mathrm{i}=1, \ldots, \mathrm{n}_{2}$;

On the basis of these errors the corrections for all weights between hidden and output layers are calculated as follows:

$$
\Delta w_{i, j}^{2}=\alpha^{2} e_{i}^{2}\left(1-y_{i}^{2}\right) y_{i}^{2} y_{j}^{1}, \mathrm{i}=1, \ldots, \mathrm{n}_{2} ; \mathrm{j}=1, \ldots, \mathrm{n}_{1} ;
$$

where $\alpha^{2}$ is the layer learning factor. Next the errors $e_{i}^{2}$ and corrected weights $w_{i, j}^{k}$ are propagated backwards in order to calculate errors of previous layer:

$$
e_{i}^{1}=\left(1 / n_{2}\right) \sum_{j=1}^{n_{2}} e_{j}^{2} w_{j, i}^{2} \quad \mathrm{i}=1, \ldots, \mathrm{n}_{1} ;
$$

Finally by analogy the corrections for all weights between input and hidden layers are computed. The training is conducted until either the defined number of iterations is performed or desired accuracy is reached. When the training is finished, the forecasts for 15 minutes ahead (N+1 st elements) are carried out on the basis of $\mathrm{N}$-element sequences applying the known weights. The quality of neural network is checked on both dependent (included in training sample) and independent (not included in training sample) data.

\section{Results of modelling and conclusion}

As usually [4,5], at first stage of modelling some attempts of model training with different inputs were carried out. In the first attempt 25 sequences of $\mathrm{N}=2$ images (the dusty concentration level) with spatial resolution $0,2 \times 0,2 \mathrm{~km}$ were applied as input. After training was complete, model quality was checked on independent data. As a result the forecast, which was carried out, was not extrapolation of images, but in fact resembled the sum of all images used as training sample. Further there were the attempts consisted in radical limitation on amount of data in input with simultaneous increase in values of other parameters (number of iterations, size of hidden layer, stochasticity level, training sample etc). Next tests, aiming at checking recognition of movements, were conducted. Training sample consisted of 38 sequences of $\mathrm{N}=2$ artificially generated images with $40 \times 40$ pixels. Neural network parameters: size of hidden layer and number of iteration was increased to 3,000 and 
10,000 respectively. Tests resulted in quite good forecast in terms of extrapolation of spot position in $\mathrm{N}+1$ st image. It indicated that in this case model was capable of learning spot movement. Taking the previous results into account attempts of applying simplified real images as input were made. Model parameters were set as in attempt with simplified artificial images. After training, the model quality was checked on both dependent and independent data. The forecast, calculated on events included in the training process, seemed to be quite correct. However in the case of independent data model did not perform well in terms of movement recognition and changes in shape and intensity of spots. Thus a size of training sample was increased to 75 sequences. The training process was repeated. Model was tested on a series of events not included in the training sample to check the model quality. The forecasts of the changes in both intensity and shape of the dusty distribution were rather not satisfactory, but in the most cases the dusty picture spot movement was extrapolated quite well. One performance of the model on the independent data is shown in Fig. 2.

Real images sequence (calibrated data) for time

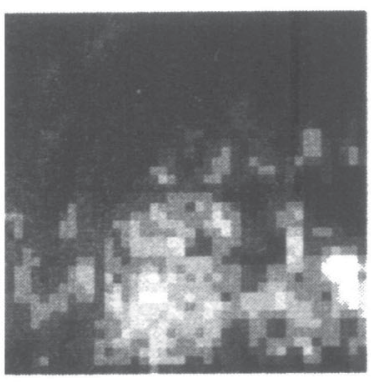

$\mathrm{t}-15$

Forecasts for time $t+15$
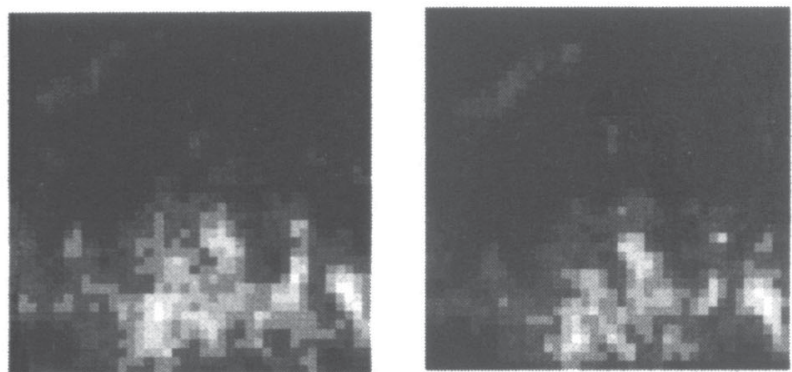

$\mathrm{t}+15$

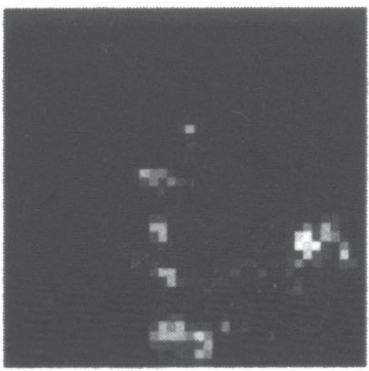

underleamt

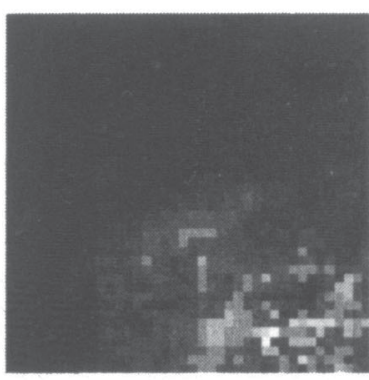

well-learmt

Fig. 2. Model performance on simplified real images

So, we at first developed a new approach to sensing temporal and spatial structure of the air pollution fields in the industrial city's atmosphere, based on the image recognition method and neural networks modelling scheme. Surely, to reach more high level of reproduction and forecast of the dust pollution field evolution in space and time, additional attempts are needed. Nevertheless, preliminary, performed neural networks modelling and analysis of the Odessa atmosphere dusty pollution filed structure and possible evolution indicates on the great perspectives of this direction in the atmosphere monitoring of industrial cities and, in general, in physics of environment, meteorology, hydrology and other sciences (c. f. [3-5]).

\section{References}

1. Zuev V. E., Zemlyanov A. A., Kopytin Yu. D., Nonlinear Optics of Atmosphere. - L., 1989.

2. Emets E. P., Novoselova A. E., Poluektov P. P., In situ determination of fractal dimension of the aerosol particles// Usp. Phys. Nauk. - 1994. Vol. 164,N9. - P. 959-967.

3. Neural Cybernetics. - AIP., New-York, 2003.

4. Glushkov A. V., Loboda A. V., Svinarenko A. A., Theory of neural networks on basis of photon echo and its program realization. - Odessa, TEC, 2004.

5. Osrydka K., Szturc J., Jurczyk A., Using neural network to precipitation nowcasting based on weather radar data// Preprint Inst. Meteorology and Water Management, Katowice, 2002.

6. Grassberger, P. and Procaccia, I., 1983. Measuring 
the strangeness of strange attractors//. Physica D. - 1983. - Vol. 9. - P. 189-208.

7. Havstad, J. W. and Ehlers, C. L., 1989. Attractor dimension of nonstationary dynamical systems from small data sets//Phys. Rev. A. — 1989. - Vol. 39. - P. 845-853.

8. Barnston A. G., Livezey R. E. Classification, seasonality and persistence of low-frequency atmospheric circulation patterns // Mon. Wea. Rev. - 1987. - Vol. 115. - P. 1083-1126.

9. Nason G., von Sachs R., Kroisand G. Wavelet processes and adaptive estimation of the evolutionary wavelet spectrum // J. Royal Stat. Soc. - 2000. - Vol. B-62. - P. 271-292.

10. Mandelbrot B. B., Fractal Geometry of Nature. N. - Y., W. H. Freeman, 1982.

11. Loboda N. S., Stochastic statistical modelling of the irrigation and man-made effects on hydrological systems and water resources// Environm. Inform. Arch. — 2003. - Vol. 1. - P. 267-273.

12. Glushkov A. V., Khokhlov V. N., Tsenenko I. A. Atmospheric teleconnection patterns and eddy kinetic energy content: wavelet analysis// Nonlinear Proc. in Geophys. - 2004. - V. 11. P. 285-293.

13. Glushkov A. V., Khokhlov V. N., Loboda N. S., Ponomarenko E. L., Computer Modelling the Global Cycle of Carbon Dioxide in System of
Atmosphere-Ocean and Environmental Consequences of Climate Change// Environm. Inform. Arch. - 2003. - Vol. 1. - P. 125-130

14. Glushkov A. V., Khokhlov V. N., Prepelitsa G. P.,Tsenenko I. A. Temporal changing atmosphere methane content: an influence of the NAO// Optics Atm. and Ocean. - 2004. - Vol. 4-C. 593-598.

15. Glushkov A. V., Prepelitsa G. P., Bunyakova Yu. Ya., Solonko T. V., Air pollution field structure in the atmosphere: stochasticity and effects of chaos in distribution of the $\mathrm{CO}$ component// Phys. Aerodisp. Syst. - 2004. - Vol. 41. - P. 127-132.

16. Glushkov A. V., Khokhlov V. N., Bunyakova Yu. Ya., Renorm-group approach to studying spectrum of the turbulence in atmosphere// Meteor. Climat. Hydrol. — 2004. - №48. - C. 286-292.

17. Bunyakova Yu. Ya.,Glushkov A. V. Laser emission analysis of the fractal dusty atmosphere parameters// Preprint of the I. I. Mechnikov Odessa Nat. Univ., NIIF., N4. - Odessa, 2004.

18. Glushkov A. V., Bunyakova Yu. Ya., Khokhlov V. N., Prepelitsa G. P.,Tsenenko I. A. Sensing air pollution field structure in the industrial city's atmosphere: stochasticity and effects of chaos// Sensor Electr. and Microsyst. Techn. — 2005. N1. - P. 21-25.

19. Bunyakova Yu. Ya. Estimating effect of the antropogenic pressing on air basin of industrial city. - Dissert. Cand. Geogr. Sci., Odessa, 2005. 